\title{
Development of a model to foster innovation culture : A study of small scale autoparts manufacturing industry of Punjab
}

\author{
B.S. SANGHA, T.P. SINGH AND AJAY BATISH
}

\begin{abstract}
Innovation has been the major strategic tool used by global organizations for dominating the global markets. Innovation as a process, which was earlier visible only in the big organizations, who serve high end markets, has now become a basic necessity in every organization and in all parts of their value chain. In the $21^{\text {st }}$ century, it's the very nature of innovation that has changed; it's happening faster, it's more open and collaborative. In a number of countries today innovation has become one of the key factors propelling economic growth and enhancing social benefits. Innovation needs to be built into the culture of an organization to enable it to gain sustainability by involving and inspiring every process associated with the organization. Innovation is a continuous process of creating new ideas and accumulation of knowledge within an enterprise. This paper investigates the combined effect of regional innovation system and organisation culture to develop a model to foster innovation culture among small-scale autoparts industry of Punjab state. The usable data from 110 small scale Autoparts enterprises was obtained through questionnaire cum interview schedule method. Model-I was developed to assess the status of innovation culture in an organisation and the Model-II helps in analyzing the influence of regional innovation system on the innovation culture of an organisation. The study revealed that regional innovation system has a strong positive influence on innovativeness of organizations.
\end{abstract}

KEY WORDS : Innovation culture, Auto part industry, Absorptive capacity, Regional innovation system

How to cite this paper : Sangha, B.S., Singh, T.P. and Batish, Ajay (2014). Development of a model to foster innovation culture : A study of small scale autoparts manufacturing industry of Punjab. Internat. J. Com. \& Bus. Manage, 7(2) : 277-283.

\section{MEMBERS OF THE RESEARCH FORUM}

Correspondence to:

B.S. SANGHA, School of Behavioural Sciences and Business Studies, Thapar University, PATIALA (PUNJAB) INDIA

Email: balwinder_sangha@yahoo.com

Authors' affiliations:

T.P. SINGH, Symbiosis International University, PUNE (M.S.) INDIA Email: tp_malik@yahoo.com

AJAY BATISH, Thapar University, PATIALA (PUNJAB) INDIA

Email: batishajay@mail.com 